\title{
Polish Society of Gynecology and Obstetrics statement on safety measures and performance of ultrasound examinations in obstetrics and gynecology during the SARS-CoV-2 pandemic
}

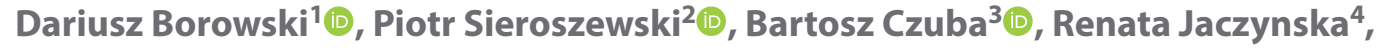

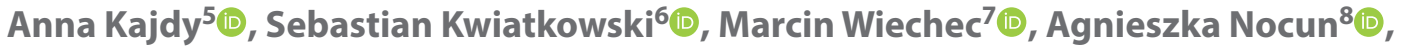

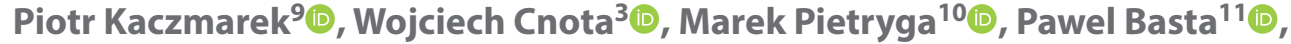 \\ Przemyslaw Kosinski ${ }^{12}$, , Michal Pomorski ${ }^{13}$ (]), Magda Rybak-Krzyszkowska ${ }^{8}$, \\ Piotr Wegrzyn ${ }^{14}$, , Miroslaw Wielgos ${ }^{12}$ (D), Mariusz Zimmer ${ }^{13}[$ \\ ${ }^{1}$ Clinic of Fetal-Maternal, Gynecology and Neonatolgy, Collegium Medicum, Nicolaus Copernicus University in Bydgoszcz, Poland \\ ${ }^{2}$ Department of Fetal Medicine and Gynecology, Medical University of Lodz, Poland \\ ${ }^{3}$ Department of Obstetrics and Gynecology in Ruda Slaska, Medical University of Silesia, Poland \\ ${ }^{4}$ Clinic of Obstetrics and Gynecology, Institute of Mother and Child, Warsaw, Poland \\ ${ }^{5}$ Department of Reproductive Health, Centre of Postgraduate Medical Education, Warsaw, Poland \\ ${ }^{6}$ Department Obstetrics and Gynecology, Pomeranian Medical University in Szczecin, Poland \\ ${ }^{7}$ Department of Gynecology and Obstetrics, Faculty of Medicine, Jagiellonian University Medical College, Cracow, Poland \\ ${ }^{8}$ Department of Obstetrics and Perinatology, University Hospital in Krakow, Poland \\ ${ }^{9}$ Operative Gynecology and Oncological Gynecology Clinic, Polish Mother's Memorial Hospital-Research Institute, Lodz, Poland \\ ${ }^{10}$ Department of Obstetrics and Women's Diseases, Poznan University of Medical Sciences, Poznan, Poland \\ ${ }^{11}$ Chair of Gynecology and Obstetrics, Department of Gynecology and Oncology, Jagiellonian University Medical College, Cracow, Poland \\ $127^{\text {st }}$ Chair and Department of Obstetrics and Gynecology, Medical University of Warsaw, Poland \\ ${ }^{13}$ Second Department of Gynecology and Obstetrics, Wroclaw Medical University, Wroclaw, Poland \\ ${ }^{14}$ Department of Obstetrics and Perinatology, Medical University of Warsaw, Poland
}

\begin{abstract}
We present recommendations on performance and safety measures of ultrasound examinations in obstetrics and gynecology during the SARS COV-2 pandemic. The statement was prepared based on the current knowledge on the coronavirus by the Ultrasound Section of the Polish Society of Obstetrics and Gynecology. It has to be noted that the presented guidance is based on limited evidence and is primarily based on experiences published by authors from areas most affected by the virus thus far, such as China, Singapore, Hong Kong, and Italy. We realize that the pandemic situation is very dynamic New data is published every day. Despite the imposed limitations related to the necessity of social distancing, it is crucial to remember that providing optimal care in safe conditions should remain the primary goal of healthcare providers. We plan to update the current guidelines as the situation develops.
\end{abstract}

Key words: pregnancy; ultrasound examination; coronavirus; prevention

Ginekologia Polska 2020; 91, 4: 231-234

\section{INTRODUCTION}

Due to the current epidemiological situation related to the SARS CoV-2 pandemic to minimize the risk of coronavi- rus transmission among ultrasound practitioners in Poland, the Ultrasound Section of the Polish Society of Gynecologists and Obstetricians has compiled recommendations 
in the field of ultrasound examinations in obstetrics and gynecology. The aim is to present the most up to date information on performance and safety measures of ultrasound examinations in obstetrics and gynecology during the SARS CoV-2 pandemic. The statement was prepared based on the current knowledge on the coronavirus and its known routes of transmission. The authors are a group of experts of the Ultrasound Section of the Polish Society of Obstetrics and Gynecology. It has to be noted that the presented guidance is based on limited evidence and is primarily based on experiences published by authors from areas most affected by the virus thus far, such as China, Singapore, Hong Kong, and Italy [1].

\section{RECOMMENDATIONS}

Ultrasound Section of the Polish Society of Gynecologists and Obstetricians recommends the following in the field of ultrasound examinations in obstetrics and gynecology:

1. An initial selection of patients should be made before carrying out an ultrasound examination by:

a) teleconsultation and completing a risk assessment of COVID-19 online with a questionnaire

or

b) telephone conversation with the patient and risk assessment by the reception employee

or

c) completing a questionnaire and epidemiological risk assessment immediately after reporting to the ultrasound performing facility.

Only patients with a negative history and asymptomatic will be scanned.

In the case of patients with an adverse epidemiological history, not feverish but with cold symptoms, it is advisable to postpone the examination until the symptoms subside.

It can be assumed that in mild cases, postponing the examination for 7 days should be sufficient.

2. Pregnant women with a positive history should be quarantined for 14 days and not have ultrasound screening. In case of emergency, hospital care in a COVID-19 dedicated center is recommended.

3. Pregnant women with COVID-19 or with a positive SARS-CoV-2 test should have ultrasound examinations performed only for justified medical indications in multidisciplinary (so-called single-purpose) centers dedicated to caring for patients with SARS-CoV- 2 infection (according to the list published by the Ministry of Health).

4. In a hospital setting, only clinically indicated examinations should be performed. These principles should be adapted to the recommendations issued by the Polish Society of Gynecologists and Obstetricians and national specialists in the field of obstetrics/gynecology and perinatology [2-4].

5. In suspected, likely or confirmed cases of COVID-19 infection, ultrasound examination of fetal growth, AFI, and umbilical artery blood flow should be performed when clinically necessary. Bedside testing is preferred. In the following weeks of pregnancy, the parameters, as mentioned above, should be monitored depending on the obstetric situation every $2-4$ weeks $[5,6]$ (Tab. 1).

6. If infection with COVID-19 is confirmed during the first or early second trimester, an ultrasound examination should be recommended between 18 and 24 weeks of pregnancy.

7. In outpatient settings, I, II, and III trimester exams should be performed. In emergencies, only if the examination cannot be performed in a hospital setting (acute abdomen, suspected ectopic pregnancy, adnexal tumor torsion, oncological patients, PID, bleeding from the genital tract of unknown etiology).

8. All other planned examinations should be postponed. (i.e., in particular 3D/4D, gynecological examinations and routine breast examinations, or monitoring of selected symptoms in obstetrics - benign dilatation of lateral ventricles of the brain, renal pelvic dilatation).

9. During obstetric examinations, due to the increased risk of transmission during a vaginal ultrasound, the number of endovaginal probe examinations should be minimized. Also, throughout the time of the epidemiological threat, cervical length should be assessed by a transabdominal examination. If the cervical length is less than $25 \mathrm{~mm}$, we recommend vaginal progesterone. There is no need to verify the measurement with a transvaginal probe. Avoid creating aerosols from potentially infectious material (vaginal discharge).

10. We carry out invasive testing following current recommendations and guidelines [7].

11. It is required to shorten the duration of the ultrasound examination, by limiting the number of parameters assessed (e.g., temporarily refraining from Ductus Venosus and Tricuspid Regurgitation assessment in fetuses with normal NT measurement in the first trimester of pregnancy) (Tab. 1).

12. It is required to limit the number of patients in the waiting room and enforce a complete restriction on the presence of accompanying persons. It is also required to maintain a distance of at least 2 meters between people.

13. It is required to keep the distance between the patient and the sonographer as large as possible.

14. During an ultrasound examination, verbal and visual contact with the patient should be limited. Consultation of the ultrasound findings should take place after completing the exam. It is essential to keep a safe distance during verbal communication. 
Table 1. Modification of routine examination depending on COVID-19 infection status/screening positive for symptoms/medical history/obstetric history and national guidelines for performance of routine ultrasound screening

\begin{tabular}{|c|c|c|c|c|}
\hline Type of scan & $\begin{array}{l}\text { Asymptomatic/negative } \\
\text { screening }\end{array}$ & $\begin{array}{l}\text { Asymptomatic/positive } \\
\text { screening }\end{array}$ & $\begin{array}{l}\text { Symptomatic/positive } \\
\text { screening }\end{array}$ & $\begin{array}{l}\text { Symptomatic/asymptomatic/ } \\
\text { positive COVID-19 }\end{array}$ \\
\hline $\begin{array}{l}<10 \text { weeks } \\
\text { viability scan, } \\
\text { pregnancy } \\
\text { dating }\end{array}$ & $\begin{array}{l}\text { Do not perform, unless heavy } \\
\text { bleeding or pain; } \\
\text { consider in patients with high risk } \\
\text { of abnormally invasive placenta* }\end{array}$ & $\begin{array}{l}\text { Do not perform, unless } \\
\text { heavy bleeding or pain; }\end{array}$ & $\begin{array}{l}\text { Do not perform, unless } \\
\text { heavy bleeding or pain; }\end{array}$ & $\begin{array}{l}\text { Do not perform, unless heavy } \\
\text { bleeding or pain; } \\
\text { if necessary, ultrasound in } \\
\text { dedicated one-purpose hospital }\end{array}$ \\
\hline 11-13.6 weeks & $\begin{array}{l}\text { Combined test } \\
\text { NT + PAPP-A + fBHCG, regardless } \\
\text { of maternal age*** } \\
\text { Offer NIPT }\end{array}$ & $\begin{array}{l}\text { Reschedule combined } \\
\text { test for at least two weeks } \\
\text { if still within gestational } \\
\text { age or CRL ( } 45-84 \mathrm{~mm} \text {, } \\
11-13.6 \text { weeks) } \\
\text { Offer NIPT, without scan at } \\
11-13.6 \text { weeks. Perform } \\
\text { a detailed scan in } \\
3-4 \text { weeks after quarantine }\end{array}$ & $\begin{array}{l}\text { Reschedule combined } \\
\text { test for at least two weeks } \\
\text { if still within gestational } \\
\text { age or CRL ( } 45-84 \mathrm{~mm} \text {, } \\
11-13.6 \text { weeks) } \\
\text { Offer NIPT, without scan at } \\
11-13.6 \text { weeks. Perform } \\
\text { a detailed scan in } \\
3-4 \text { weeks after quarantine }\end{array}$ & $\begin{array}{l}\text { Reschedule combined test for } \\
\text { at least two weeks if still within } \\
\text { gestational age or CRL ( } 45-84 \mathrm{~mm} \text {, } \\
11-13.6 \text { weeks) } \\
\text { Offer NIPT, without scan at } \\
11-13.6 \text { weeks. Perform a detailed } \\
\text { scan in } 3-4 \text { weeks after quarantine } \\
\text { If necessary, perform ultrasound in } \\
\text { a dedicated one-purpose hospital }\end{array}$ \\
\hline $18-22$ weeks & Anomaly scan & $\begin{array}{l}\text { Reschedule after } \\
\text { quarantine in } \\
2-3 \text { weeks }^{* * *}\end{array}$ & $\begin{array}{l}\text { Reschedule after } \\
\text { quarantine in } \\
2-3 \text { weeks }^{* * *}\end{array}$ & $\begin{array}{l}\text { Reschedule after quarantine in } \\
2-3 \text { weeks*** }\end{array}$ \\
\hline $\begin{array}{l}\text { Fetal growth } \\
\text { scan in the } \\
\text { thirdtrimester } \\
28-32 \text { weeks }\end{array}$ & $\begin{array}{l}\text { Do not perform, unless clinically } \\
\text { indicated; assess risk factors of } \\
\text { fetal growth restriction during } \\
\text { a teleconsultation; } \\
\text { Perform scan only in high-risk } \\
\text { patients for abnormal fetal growth }\end{array}$ & $\begin{array}{l}\text { Do not perform, unless } \\
\text { clinically indicated; assess } \\
\text { fetal growth } 2-3 \text { weeks } \\
\text { after quarantine to screen } \\
\text { for fetal growth restriction }\end{array}$ & $\begin{array}{l}\text { Do not perform, unless } \\
\text { clinically indicated; assess } \\
\text { fetal growth } 2-3 \text { weeks } \\
\text { after quarantine to screen } \\
\text { for fetal growth restriction }\end{array}$ & $\begin{array}{l}\text { Do not perform, unless clinically } \\
\text { indicated; assess fetal growth } \\
2-3 \text { weeks after quarantine to } \\
\text { screen for fetal growth restriction } \\
\text { If necessary, perform ultrasound in } \\
\text { a dedicated one-purpose hospital }\end{array}$ \\
\hline $\begin{array}{l}\text { Twin } \\
\text { pregnancies }\end{array}$ & $\begin{array}{l}\text { According to national ministerial } \\
\text { recommendations }\end{array}$ & $\begin{array}{l}\text { According to } \\
\text { national ministerial } \\
\text { recommendations; } \\
\text { Perform scan in } 2 \text { weeks } \\
\text { after quarantine }\end{array}$ & $\begin{array}{l}\text { According to } \\
\text { national ministerial } \\
\text { recommendations; } \\
\text { Perform scan in } 2 \text { weeks } \\
\text { after quarantine }\end{array}$ & $\begin{array}{l}\text { According to national ministerial } \\
\text { recommendations; Perform } \\
\text { scan in } 2 \text { weeks after quarantine; if } \\
\text { necessary, perform ultrasound in } \\
\text { a dedicated one-purpose hospital }\end{array}$ \\
\hline
\end{tabular}

*Women with more than two cesarean sections, previous AIP, > 3 miscarriages with ECU or previous ectopic pregnancy; **in Poland the national prenatal screening program is free of charge only for women $>35$ or with a previous or family history of congenital abnormalities; ***if high risk for abnormalities that fit the national laws for termination of pregnancy, inform the patient of time frame and rights if necessary perform ultrasound/invasive diagnosis in full protection

15. Only the patient can stay in the office and waiting room - no accompanying persons. It is strictly prohibited, bringing children to the medical facility.

\section{RECOMMENDED PERSONAL PROTECTIVE EQUIPMENT}

1. At least a surgical mask for the doctor and midwife, in case the staff is infected and asymptomatic, to avoid exposure of the pregnant woman. The mask also reduces the frequency of contact with the mouth and nose, which we often touch unknowingly. The availability of masks is limited.

2. We recommend promoting safe behaviors. Every patient should attend the scan visit wearing a face mask. Many patients may be asymptomatic, causing a threat of spreading the virus while speaking. This threat is not only to medical practitioners but to other patients present in the facility. The virus lasts a long time in the air, and often there is no possibility of airing the office during the day. It is recommended to air the office several times a day.

3. Protective goggles.
4. An ideal mask would be a mask with an FFFP2 (N95) or FFP3 (N100) filter. The availability of masks is limited.

5. Perform the ultrasound examination in disposable gloves.

6. Hand wash and disinfect after each examination - optimally using a dispenser without aerosol production [8]!

\section{CLEANING AND DISINFECTION OF THE DEVICE - ACCORDING TO THE MANUFACTURER'S INSTRUCTIONS}

1. After each patient, use a cloth soaked in disinfectant to clean the probes and surfaces of the device.

2. Since information about COVID-19 is incomplete, it is recommended to use high-level disinfectants

3. High-level disinfectants include:

a) ethanol $80-95 \%$ (exposure time $30 \mathrm{sec}$ ),

b) 2-propanol $75-00 \%$ (exposure time $30 \mathrm{sec}$ ),

c) 2-propanol and 1-propanol $45 \%$ and $30 \%$ (exposure time $30 \mathrm{sec}$ ),

d) sodium hypochlorite $0.21 \%$ (Antisapril Blu $2 \%$, exposure time $30 \mathrm{sec}$ ),

e) glutaraldehyde $2.5 \%$ (exposure time $5 \mathrm{~min}$ ), 
f) hydrogen peroxide $0.5 \%$ (REVITAL-OX RESERT, exposure time $1 \mathrm{~min}$ ).

4. Protective eyewear and gloves should be used when cleaning, disinfecting or sterilizing any equipment [1,9].

\section{SUMMARY}

We realize that the pandemic situation is very dynamic. New data is published every day. Despite the imposed limitations related to the necessity of social distancing, it is crucial to remember that providing optimal care in safe conditions should remain the main goal of healthcare providers. We plan to update the current guidelines as the situation develops.

\section{Conflict of interest}

The authors declare that there is no conflict of interest in the presented recommendations.

\section{REFERENCES}

1. ISUOG Safety Committee Position Statement on use of personal protective equipment and hazard mitigation in relation to SARS-CoV-2 for practitioners undertaking obstetric and gynecological ultrasound. https://www.isuog.org/resource/isuog-safety-committee-position-statement-on-use-of-personal-protective-equipment-and-hazard-mitigation-in-relation-to-sars-cov-2-for-practitioners-undertaking-obstetric-and-gynecological-ultrasound.html (2.04.2020).

2. Rozporządzenie Ministra Zdrowia z dnia 9 listopada 2015 r. w sprawie standardów postępowania medycznego przy udzielaniu świadczeń zdrowotnych w dziedzinie położnictwa i ginekologii z zakresu okołoporodowej opieki położniczo-ginekologicznej, sprawowanej nad kobietą w okresie ciąży, porodu, połogu, w przypadkach występowania określonych powikłań oraz opieki nad kobietą w sytuacji niepowodzeń położniczych. https://www. infor.pl/akt-prawny/DZU.2015.234.0002007,rozporzadzenie-ministra-zdrowia-w-sprawie-standardow-postepowania-medycznego-przy-udzielaniu-swiadczen-zdrowotnych-w-dziedzinie-poloznictwa-i-ginekologii-z-zakresu-okoloporodowej-opieki-polozniczogine. html (2.04.2020).

3. Bomba-Opoń D, Wielgoś M. Standardy opieki okołoporodowej w przypadkach występowania określonych powikłań. Ginekol Perinatol Prakt. 2016; 1(1): 1-9.

4. Polish Gynaecological Society Guideline on Prenatal Diagnosis. Polish Gynecological Society - Ultrasound Section Guidelines on ultrasound screening in uncomplicated pregnancy - 2015. Ginekol Pol. 2015; 86(7): 551-558, doi: 10.17772/gp/58642.

5. Rasmussen SA, Smulian JC, Lednicky JA, et al. Coronavirus Disease 2019 (COVID-19) and pregnancy: what obstetricians need to know. Am J Obstet Gynecol. 2020 [Epub ahead of print], doi: 10.1016/j.ajog.2020.02.017, indexed in Pubmed: 32105680.

6. Qiao J. What are the risks of COVID-19 infection in pregnant women? Lancet. 2020; 395(10226): 760-762, doi: 10.1016/S0140-6736(20)303652, indexed in Pubmed: 32151334

7. Polish Gynaecological Society Guideline on Prenatal Diagnosis. [Polish Gynaecological Society guideline on prenatal diagnosis]. Ginekol Pol. 2009; 80(5): 390-393, indexed in Pubmed: 19548462.

8. European Centre for Disease Prevention and Control. Guidance for wearing and removing personal protective equipment in healthcare settings for the care of patients with suspected or confirmed COVID-19. Stockholm: ECDC, 2020

9. Kampf G, Todt D, Pfaender S, et al. Persistence of coronaviruses on inanimate surfaces and their inactivation with biocidal agents. J Hosp Infect. 2020; 104(3): 246-251, doi: 10.1016/j.jhin.2020.01.022, indexed in Pubmed: 32035997 